\title{
Streptococcus porcinus Endocarditis: The First Reported Case In Humans
}

\author{
Streptococcus porcinus Endokarditi: İnsanlarda Bildirilen İlk Olgu \\ Nur Cancan Gursul', Emre Ozdemir ${ }^{2}$ \\ ${ }^{1}$ Canakkale Mehmet Akif Ersoy State Hospital, Department of Infectious Disease and Clinical Microbiology, Çanakkale, Turkey \\ ${ }^{2}$ Izmir Katip Celebi University Ataturk Training and Research Hospital, Department of Cardiology, Izmir, Turkey
}

\begin{abstract}
Streptococcus porcinus is a beta hemolytic streptococcus and was first isolated from swine in the year 1937. It can cause cellulitis, endocarditis, sepsis, cervical lymphadenitis and spontaneous abortions in animals, especially pigs. In humans the microorganism has been isolated from blood, wound, placenta, urine, cervix and vagina. A few case of invasive $S$. porcinus infections (bacteremia and brain abscess) have been reported to date. In available literature no case of endocarditis caused by S.porcinus was found to date. In this article we present the first reported case of Streptococcus porcinus endocarditis in humans; in a 29-year-old pregnant woman to emphasize that this organism can cause severe infections like infective endocarditis.
\end{abstract}

Key words: Streptococcus porcinus, Infective Endocarditis, Endocarditis in Pregnancy

\section{INTRODUCTION}

Endocarditis is an infection of the endothelial surface of the heart. It is still an important problem for clinicians because of its mortality, morbidity and serious complications (1). Streptococcus species especially viridans streptococcus are commonly associated with endocarditis. The other streptococcus species are rarely reported $(1,2)$.

Streptococcus porcinus is a beta-hemolytic streptococci in Lancefield group NG1 (A1, C1), NG2, NG3, E, P, U, or $\mathrm{V}$ antigen (3). Pigs, sheep, rabbits, dogs, guinea pigs, and cattle can be a reservoir for $S$. porcinus (3). In pigs it has been shown to colonize the genital and upper respiratory tracts and it can be caused cellulitis, endocarditis, sepsis, cervical lymphadenitis and spontaneous abortion $(4,5)$. In humans a few case of S.porcinus infections were reported and most of them

\section{ÖZET}

Streptococcus porcinus ilk olarak 1937 yilında domuzdan izole edilen bir beta hemolitik streptokoktur. Hayvanlarda; özellikle domuzlarda selülit, endokardit, sepsis, servikal lenfadenit ve spontan düşüklere neden olabilir. İnsanlarda kan, yara, plasenta, idrar, serviks, vajinadan izole edilmiştir ve bugüne kadar az sayıda invaziv S. porcinus enfeksiyonu (bakteriyemi ve beyin absesi) bildirilmiştir. Ulaşılabilen literatürde Streptococcus porcinus'un neden olduğu endokardit olgusuna rastlanmamıştır. Bu yazıda 29 yaşında hamile bir kadında tanı koyduğumuz, insanlarda bildirilen ilk Streptococcus porcinus endokardit olgusunu, bu organizmanın infektif endokardit gibi ciddi enfeksiyonlara yol açabileceğini vurgulamak için sunuyoruz.

Anahtar Kelimeler: Streptococcus porcinus. İnfektif endokardit, Gebelikte Endokardit

are genitourinary tract infections in women $(3,5)$. In this article, we present a case of endocarditis caused by $S$. porcinus to draw attention that it can cause serious invasive infections and lead to life-threatening outcomes.

\section{CASE REPORT}

A 22-week pregnant female patient was admitted to the obstetrics and gynecology outpatient clinic with complaints of fever, loss of appetite, weight loss, weakness and shortness of breath for 4 weeks. She was 29 years old and had no other known disease other than valvular heart diseases. At the time of admission she had fever to $38.2^{\circ} \mathrm{C}$. Her blood pressure was 128/65 mm $\mathrm{Hg}$ and heart rate was 108 beats/minute. Initial physical examination revealed grade $3 / 6$ systolic murmur at mitral focus. Peripheral 
signs of infective endocarditis such as Osler's nodule and Janeway lesion were absent. The rest of her physical examination was unremarkable.

The patient was consulted with cardiologist. On transthoracic echocardiography $10 \mathrm{~mm}$ dimensions vegetation on the mitral valve anterior leaflet was detected and the patient was admitted to the cardiology clinic with a prediagnosis of infective endocarditis. After 4 blood cultures were taken ceftriaxone $1^{*} 2 \mathrm{gr} /$ day i.v was started empirically. On the second day of admission she was evaluated by a perinatology specialist. Because of the major malformation of the fetus termination was recommended by the perinatology council and the fetus was terminated at 22 weeks of gestation.

On admission a white blood cell count of $6,7 \mathrm{~K} / \mathrm{uL}$ with $76,6 \%$ neutrophils, haemoglobin of $8,8 \mathrm{~g} / \mathrm{dL}$, hematocrit of $26,7 \%$ and platelets of $211 \mathrm{~K} / \mathrm{uL}$, C-reactive protein (CRP) of $2,19 \mathrm{mg} / \mathrm{dl}$, erythrocyte sedimentation rate (ESR) of $88 \mathrm{~mm} / \mathrm{h}$ and procalcitonin of $0.01 \mathrm{ng} / \mathrm{mL}$. The other laboratory tests were in normal range. Four blood culture samples incubated to BACTEC 9240 (Becton Dickinson Instrument System, Sparks, USA) and in three of them S.porcinus grew up. Identification of the microorganism was performed by Phoenix $100^{\mathrm{TM}}$ (Becton Dickinson Instrument System, Sparks, USA). Antibiotic susceptibility of the grown microorganism was determined by using the disc diffusion method according to the Clinical Laboratory Standard Institute criteria (6). S.porcinus grew in three of the four blood cultures taken and it was susceptible to amoxicillin, amoxicillin/clavulanic acid, cefuroxime, ceftriaxone, cefepim, ciprofloxacin, erythromycin, clindamycin and vancomycin.

Ejection Fraction (EF) was calculated $60 \%$ on transthoracic echocardiography on admission. Approximately $10^{\star} 10 \mathrm{~mm}$ dimensions mobile mass was seen on the anterior mitral leaflet with grade 3 mitral regurgitation. Restricted mitral leaflet movement was observed due to calcification of leaflets. Mitral valve peak/ mean gradient were calculated $28 \mathrm{mmHg} / 18$ $\mathrm{mmHg}$. Mitral valve area was measured $1,3 \mathrm{~cm} 2$ with Doppler pressure half-time. Grade 4 aortic regurgitation was seen on aortic valve without significant gradient increase.

Under the ceftriaxone treatment her symptoms were improved and the vegetation size decreased from 10 $\mathrm{mm} \times 10 \mathrm{~mm}$ to $5 \mathrm{~mm} \times 6 \mathrm{~mm}$. There was no growth in blood cultures taken while antibiotic treatment was continued but at the $4 \mathrm{rd}$ week of antibiotic treatment shortness of breath and weakness started again. On transesophageal echocardiography, the vegetation size was calculated $5 \mathrm{~mm} \times 6 \mathrm{~mm}$. Severe mitral regurgitation (grade 4 ) was detected. Approximately 2 $\mathrm{mm}$ width defect was observed on anterior mitral leaflet due to perforation of valve. Different mitral regurgitant jet was seen on perforation side apart from center severe mitral regurgitant jet. With this clinical and echocardiography findings the patient underwent mechanical mitral and aortic valve replacement on the 35 th day of antibiotic treatment was started. The patient's general condition improved after surgery, and was discharged with warfarin treatment and outpatient control.

\section{DISCUSSION}

Infective endocarditis (IE) is an infectious disease of endocardium of heart that involves the cardiac valves (native or prosthetic) or an indwelling cardiac device. The incidence of IE has been reported to be ranging from 3 to 7 per 100000 person-years (2). Although it is rare, it maintains its importance due to high mortality, morbidity and severe complication (1). During pregnancy, the incidence of IE has been reported to be $0.006 \%$ and in patients with cardiac disease the incidence is $0-1.2 \%(7,8)$. Our patient had valvular 
diseases before pregnancy and according to the literature in pregnancy IE develops either as a complication of a pre-existing cardiac lesion or as a result of intravenous drug abuse (8).

Streptococcus porcinus is belonging to Lancefield serological groups $\mathrm{E}, \mathrm{P}, \mathrm{U}$, and $\mathrm{V}$. It is a beta-hemolytic streptococci and first isolated from swine in 1937 (3). It can cause infections both in animals and humans (3-5). In 2005 Duarte et al. reported phenotypic and genotypic characteristics of 25 S.porcinus strains from human sources and most of the strains are isolated from genitourinary tract specimens (5). S. porcinus infections in humans are infrequent and severe invasive infection like brain abscess, bacteremia etc. has been reported in only a few cases $(3,5,9)$.

In studies $S$. porcinus infections during pregnancy have been associated with vaginal colonization, corioamnioitis and spontaneous preterm stillbirth $(10,11)$. Our patient was 22-week pregnant on admission. She lived in a village and had close contact with animals. We think that she may have colonized beforehand, but we do not have any data to prove this. In IE during pregnancy fetal mortality is reported to be about $29 \%$ (8). On follow up the fetus was terminated because of major congenital malformation of the fetus, not because of a complication of endocarditis.

The patient had two major criteria (positive blood culture and endocardial involvement) and two minor criteria (fever and predisposing heart condition) according to the modified Duke's criteria. So she met criteria for definitive endocarditis. Medical management with antibiotics is the first choice of treatment in infective endocarditis $(1,7)$. S.porcinus is mostly susceptible to many antibiotics like penicillin, amoxicillin, cefuroxime, ceftriaxone, cefepim, ciprofloxacin, erythromycin, clindamycin, levofloxacin, trimethoprim-sulfamethoxazole and vancomycin but most of the colonies resistance to tetracycline $(3,5)$. We started ceftriaxone $1 \times 2 \mathrm{gr} /$ day i.v treatment empirically before the blood cultures resulted and because of the growth of S.porcinus in the blood culture we continued the treatment.

The most frequent complication and indication for surgery in IE is heart failure and it presents with dyspnea, pulmonary oedema and cardiogenic shock $(7,12)$. Heart failure results from new or worsening severe aortic or mitral regurgitation primarily as a result of mitral cord rupture, leaflet tear (pseudoleaf), leaflet perforation, or interaction of vegetation mass with leaflet closure. These lesions are best detected using TOE $(7,12)$. In our patient, regression in symptoms and reduction in vegetation size were achieved with ceftriaxone treatment, but during follow up surgical treatment had to be applied to the patient who developed heart failure due to valve perforation.

As a result; $S$. porcinus has been reported rarely as an infectious agent in humans. Most of the reported case in the literature is genitourinary tract infection like corioamnioitis, vaginitis. Although it seems susceptible to many antibiotics and easily treatable with antibiotic therapy, it should be remembered that it can also cause life-threatening infections such as infective endocarditis and should be treated appropriately.

Informed Consent: Informed consent was taken from the patient.

Conflict of Interest: The authors declare that they have no conflict of interest.

Funding: No funding was received for this research.

\section{REFERENCES}

1. Baddour LM, Wilson WR, Bayer AS, et al. Infective Endocarditis in Adults: Diagnosis, Antimicrobial Therapy, and Management of Complications: A Scientific Statement for Healthcare Professionals From the American Heart Association. Circulation. 2015 Oct 13;132(15):1435-86.

2. Correa de Sa DD, Tleyjeh IM, Anavekar NS, et al. Epidemiological trends of infective endocarditis: a populationbased study in Olmsted County, Minnesota. Mayo Clin Proc. 2010 May;85(5):422-6. 
3. Facklam R, Elliott J, Pigott N, Franklin AR. Identification of Streptococcus porcinus from human sources. J Clin Microbiol. $1995 \mathrm{Feb} ; 33(2): 385-8$.

4. Bağcıgil AF, İkiz S, Metiner K,Özgür NY, Ak S, Ilgaz AA. Isolation of Streptococcus species from the tonsils of slaughtered pigs. Turk J Vet Anim Sci. 2013; 94-6.

5. Duarte RS, Barros RR, Facklam RR, Teixeira LM. Phenotypic and genotypic characteristics of Streptococcus porcinus isolated from human sources. J Clin Microbiol. 2005 Sep;43(9):4592-601.

6. Cockerill FR, Patel JB, Alder $\mathrm{J}$ et al. Clinical and Laboratory Standarts Institue M100-S23 Performance standards for antimicrobial susceptibility testing. 23rd Informational Supplement. Wayne, Pennsylvania. Clinical and Laboratory Standarts Institue. 2013

7. Habib G, Lancellotti P, Antunes MJ, et al. 2015 ESC Guidelines for the management of infective endocarditis: The Task Force for the Management of Infective Endocarditis of the European Society of Cardiology (ESC). Endorsed by: European Association for Cardio-Thoracic Surgery (EACTS), the European Association of Nuclear Medicine (EANM). Eur Heart J. 2015 Nov 21;36(44):3075-128.

8. Montoya ME, Karnath BM, Ahmad M. Endocarditis during pregnancy. South Med J. 2003 Nov;96(11):1156-7.

9. Martínez Bustamante D, Pérez Cárdenas S, Arteaga Treviño M, Martínez Ponce de León ÁR. Emerging pathogens in the central nervous system: a cerebral abscess by Streptococcus porcinus. Medicina universitaria. 2015;177-80.

10. Gullett JC, Westblade LF, Green DA, Whittier S, Burd EM. The Brief Case: Too Beta To Be a "B". J Clin Microbiol. 2017 Jun;55(6):1604-7.

11. Martin C, Fermeaux V, Eyraud JL, Aubard Y. Streptococcus porcinus as a cause of spontaneous preterm human stillbirth. J Clin Microbiol. 2004 Sep;42(9):4396-8.

12. Nadji G, Rusinaru D, Rémadi JP, Jeu A, Sorel C, Tribouilloy C. Heart failure in left-sided native valve infective endocarditis: characteristics, prognosis, and results of surgical treatment. Eur J Heart Fail. 2009 Jul;11(7):668-75.

Cite as: Cancan Gursul N, Ozdemir E. Streptococcus porcinus Endocarditis: The First Reported Case In Humans.

Eskisehir Med J. 2022;3(1):1-4. 